\title{
SARS-CoV-2 Variants: Mutations and Effective Changes
}

\author{
Gene Park and Byeong Hee Hwang
}

Received: 27 October 2021 / Revised: 14 November 2021 / Accepted: 14 November 2021

(C) The Korean Society for Biotechnology and Bioengineering and Springer 2021

\begin{abstract}
One of the primary threats to the goal of controlling and eventually defeating SARS-CoV-2 is that of mutation. Recognizing this, a great amount of effort and dedicated study is being given to the matter. Due to the novel coronavirus's general prevalence and rate of mutation, this is an extremely dynamic area with constant new developments. Therefore, understanding the virus's pathogenesis and how mutations affect it is crucial. This review attempts to aid in understanding the currently most important strains and what primary changes they entail in connection to more specific mutations, and how they each affect infectivity, antigen resistance, and other properties. In an attempt to maintain relevance to the time at which this paper will be published, priority has been given to variants classified by the WHO and the CDC as of Sep. 23, 2021, as "Variants of Concern". Of particular interest in B.1.1.7, B.1.351, B.1.617.2, P.1 are the mutations affecting the Spike protein and Receptor Binding Domain, as they directly affect infectivity and susceptibility to neutralization. Certain mutations (D614G, E484K, N501Y, K417N, L452R, and P681R) have appeared across several different strains, often accompanied by others that may be complementary working together to confer increased infectivity, fitness, or resistance to neutralization. We anticipate that the understanding of such COVID-19 mutations will, in the near future, prove important for diagnosis, treatment development, and vaccine development.
\end{abstract}

Gene Park

Whitmore School, Morgantown, WV 26505, USA

Byeong Hee Hwang*

Division of Bioengineering, Incheon National University, Incheon 22012, Korea

Department of Bio-nanobioengineering, Incheon National University, Incheon 22012, Korea

Tel: +82-32-835-8834; Fax: +82-32-835-0804

E-mail: bhwang@inu.ac.kr
Keywords: SARS-CoV-2, variants, mutation, infectivity, neutralization

\section{Introduction}

COVID-19 was formally declared a global pandemic by the WHO on Mar. 11, 2020 [1]. Since then, the virus has caused at least 3 million deaths worldwide, crippled the scope of events on all scales, and caused untold damage to the global economy. In recent months, progress towards controlling the pandemic has been met with the obstacle of new variants, which display increased transmissibility and lethality. VOCs, "variant(s) for which there is evidence of an increase in transmissibility, more severe disease... significant reduction in neutralization by antibodies generated during previous infection or vaccination, reduced effectiveness of treatments or vaccines, or diagnostic detection failures" by the WHO are especially relevant to the current pandemic landscape. Of particular interest are their mutations in the $\mathrm{S}$ protein (ref seq. loc. 21,56325,384, gi|1798174254|ref|NC_045512.2|), which have the most direct potential to affect key characteristics of the virus, including infectivity and susceptibility to neutralization. There is, understandably, some slight disorganization surrounding the properties and specific mutations of different SARS-CoV-2 strains, given the unprecedented outpour of research on the matter. Sources on occasion give conflicting information on the more minute details [24]. While previous work has addressed the properties of variants very clearly, comparatively little attention has as of yet been directed to giving a detailed review of the effects of individual mutations. The explicit examination of mutations underlying the properties of variants and the drawing of conclusions from these examinations is also lacking or usually not addressed for more than a few 
A

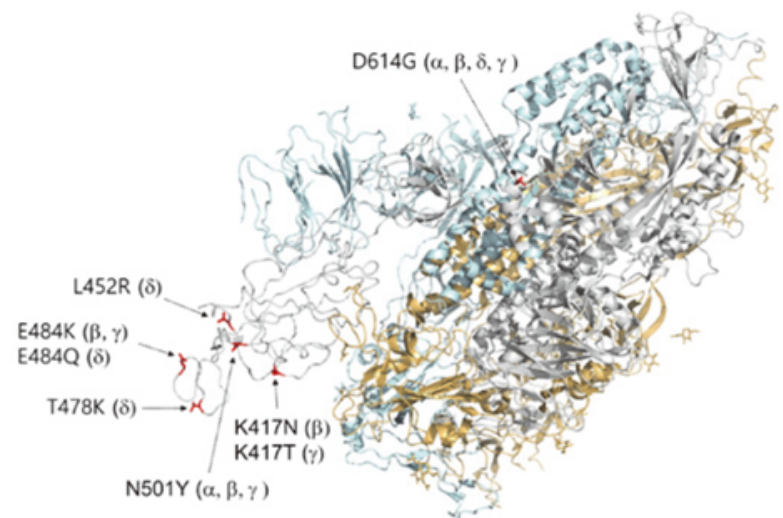

D

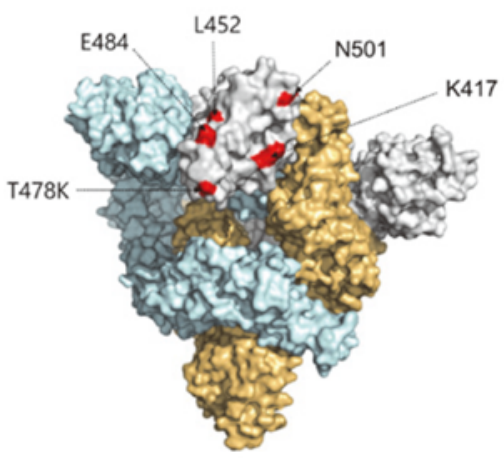

B

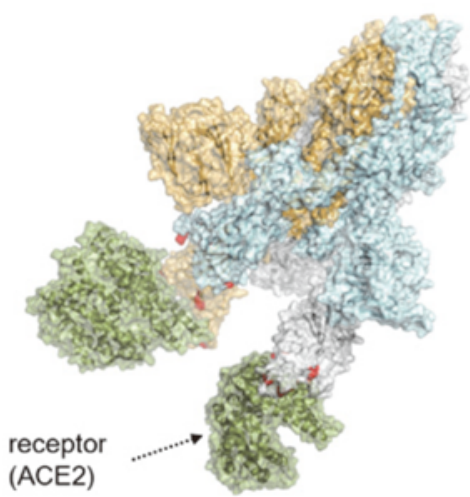

C

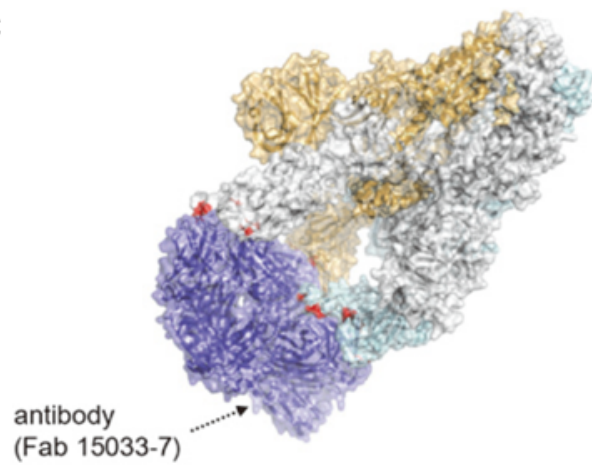

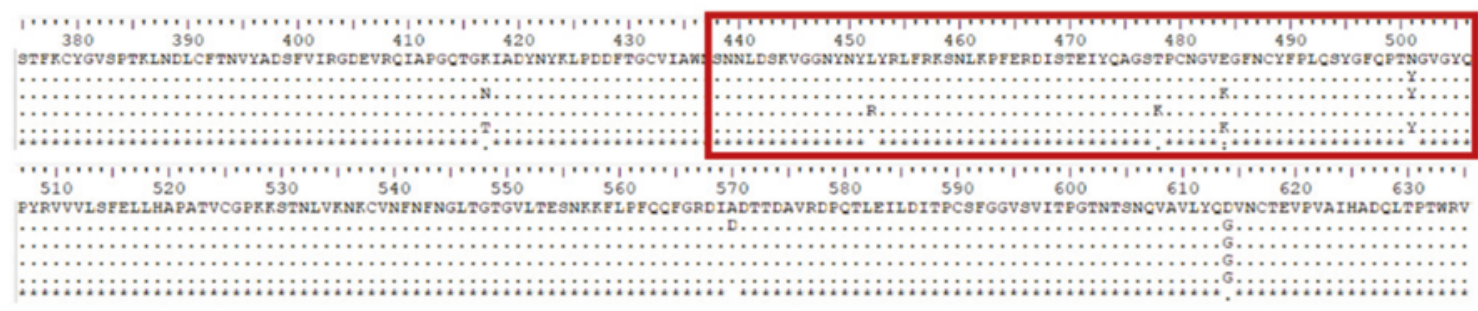

Fig. 1. 3-dimensional structures of SARS-CoV-2 spike (S) protein. (A) 3D ribbon model of S protein (upper) and the bottom view of its 3D surface model (lower) [82]. Red spots indicate the position of mutated amino acids. (B) 3D surface model of ACE2 receptor-bound $\mathrm{S}$ protein [83]. (C) 3D surface model of Fab 15033-7 antibody-bound S protein [84]. All structure figures were generated with PyMol [85]. (D) S protein sequence alignment of variants using ClustalW of BioEdit. The red box indicates the receptor-binding motif.

mutations found within a lineage. It is not bold, therefore, to suggest that this paper's reviewing of how mutations affect the virus, drawing of connections, and creation of comparisons would be useful for people, both professional and civilian, to understand the virus and how it has evolved so far. Here, we provide a description of key mutations in the SARS-COV-2 S protein, summarize their characteristics, and examine the VOCs that they are present in (Fig. 1).

\section{Specific Mutations}

\subsection{D614G}

D614G emerged early in the pandemic and quickly became one of the most common mutations in SARS CoV-2 in Table 1 [5]. The change from aspartic acid to glycine induces a neutral charge from a negative charge and reduces the steric hindrance of the functional group. The most notable change that it brings is its increased infectivity due to a stronger binding affinity for the angiotensin-converting enzyme 2 (ACE2) receptor [5-9]. The D614G mutation facilitates an open conformational state of the $\mathrm{S}$ protein [10]. Therefore, a higher binding rate could increase the infectivity of SARS-CoV-2 variants with D614G. Moreover, variants with the mutation are predicted to be more sensitive to antibody neutralization due to increased RBD exposure. In fact, some research has found that SARS CoV-2 expressing G614 has higher neutralization titers than those with D614, suggesting that it is more susceptible to neutralization by antibodies, though this change is very moderate [11], and effective resistance is mostly unchanged [8]. This is possible because the G614 spike leads to a higher percentage of 1-RBD "up" configurations in the spike, from $46 \%$ to $82 \%$ according to negative stain electron 
Table 1. Factors affecting Infectivity and Resistance to antibodies

\begin{tabular}{|c|c|c|c|c|c|c|}
\hline Mutation & $\begin{array}{l}\text { Seen in } \\
\text { strains: }\end{array}$ & $\begin{array}{c}\text { Effects on } \\
\text { Transmissibility }\end{array}$ & $\begin{array}{c}\text { Effects on } \\
\text { neutralization } \\
\text { sensitivity (mAbs) }\end{array}$ & $\begin{array}{c}\text { Effects on } \\
\text { neutralization } \\
\text { sensitivity (sera) }\end{array}$ & $\begin{array}{l}\text { Effects on } \\
\text { virulence }\end{array}$ & Additional remarks \\
\hline $\begin{array}{l}\text { D614G } \\
\text { Spike } \\
\text { Mutation }\end{array}$ & $\begin{array}{l}\text { B.1.1.7, } \\
\text { B.1.351, } \\
\text { B.1.617.2, P.1 }\end{array}$ & Increased [5-9]. & $\begin{array}{l}\text { Negligible. } \\
\text { Reduced for } \\
\text { CR3022 [12]. }\end{array}$ & $\begin{array}{l}\text { Negligible }[8] . \\
\text { Potentially } \\
\text { increased }[9,11] .\end{array}$ & $\begin{array}{l}\text { Greater viral } \\
\text { load }[6,9,12] . \\
\text { No increase in } \\
\text { disease } \\
\text { severity }[13] .\end{array}$ & $\begin{array}{l}\text { The increase in } \\
\text { neutralization sensitivity is } \\
\text { quite moderate [11]. } \\
\text { D614G alone should not } \\
\text { affect vaccine } \\
\text { development or the risk of } \\
\text { reinfection. }\end{array}$ \\
\hline $\begin{array}{l}\text { E484K } \\
\text { Spike } \\
\text { Mutation }\end{array}$ & B.1.351, P.1 & $\begin{array}{l}\text { Increased. } \\
\text { Stronger binding } \\
\text { affinity with ACE2 } \\
{[15-17] \text {. }}\end{array}$ & Reduced $[21,22]$. & $\begin{array}{l}\text { Reduced. } \\
\text { Up to } 10 \text { fold } \\
\text { against plasma in } \\
\text { some instances [18- } \\
20] \text {. }\end{array}$ & $\begin{array}{l}\text { No } \\
\text { information }\end{array}$ & $\begin{array}{l}\text { It is referred to as an } \\
\text { escape mutation as that is } \\
\text { its primary effect on the } \\
\text { virus. Its effect on } \\
\text { infectivity is relatively } \\
\text { moderate. }\end{array}$ \\
\hline N501Y & B.1.1.7, P.1 & $\begin{array}{l}\text { Increased [42]. } \\
\text { Stronger binding } \\
\text { affinity [26-30]. } \\
\text { Up to } 7.1 \text { fold } \\
\text { affinity increase } \\
\text { [15]. }\end{array}$ & $\begin{array}{l}\text { Negligible [34]. } \\
\text { Reduced for certain } \\
\text { antibodies [4,33] } \\
\text { such as COVA1-12, } \\
\text { RBD-chAb25, and } \\
\text { CB6 [31,32]. }\end{array}$ & Negligible $[4,34]$. & $\begin{array}{l}\text { Increased } \\
\text { lethality (With } \\
\text { K417N) [17]. }\end{array}$ & \\
\hline $\begin{array}{l}\text { K417N } \\
\text { Spike } \\
\text { Mutation }\end{array}$ & $\begin{array}{l}\text { B.1.351 } \\
\text { B.1.617.2 }\end{array}$ & $\begin{array}{l}\text { Decreased (when } \\
\text { isolated). Lowers } \\
\text { ACE2 affinity } \\
{[15,26] \text { by }} \\
1.48 \mathrm{kcal} / \mathrm{mol} \\
{[35] .}\end{array}$ & Negligible [26]. & Negligible [26]. & $\begin{array}{l}\text { Increased } \\
\text { lethality (With } \\
\text { N501Y) [17]. }\end{array}$ & $\begin{array}{l}\mathrm{K} 417 \mathrm{~N} \text { is an outlier } \\
\text { because its effect is mainly } \\
\text { negative. It has been } \\
\text { hypothesized that it has } \\
\text { been selected by evolution } \\
\text { because of its conferring of } \\
\text { resistance to human } \\
\text { antibody CB6 [35]. }\end{array}$ \\
\hline $\begin{array}{l}\text { L452R } \\
\text { Spike } \\
\text { Mutation }\end{array}$ & B.1.617.2 & $\begin{array}{l}\text { Increased [37]. } \\
\text { Estimates range } \\
\text { from } 18.6-24 \% \\
\text { over WT [38]. }\end{array}$ & Reduced [40]. & Reduced [38-40]. & Increased [38]. & $\begin{array}{l}\text { Effects of escape from } \\
\text { mAb neutralization are } \\
\text { likely cumulative with } \\
\text { others in the S protein } \\
\text { [40]. }\end{array}$ \\
\hline $\begin{array}{l}\text { P681R } \\
\text { Spike } \\
\text { mutation }\end{array}$ & B.1.617.2 & Negligible [42]. & Negligible [42]. & Negligible [41,42]. & $\begin{array}{l}\text { Increased } \\
{[41,42] .}\end{array}$ & $\begin{array}{l}\text { Data regarding P681R is } \\
\text { relatively new and would } \\
\text { benefit from further study. }\end{array}$ \\
\hline
\end{tabular}

microscopy from Weissman et al. [11]. This phenomenon implies that D614G is not included in the epitope of the antibodies and/or that G614 might, in some cases, strengthen the interaction with antibodies via reasons similar to ACE2 binding affinity. While not a cause of concern in vaccine development, it does enhance infectivity as well as viral fitness, i.e., viral stability and infectivity. It was associated with significantly increased viral loads in parts of the respiratory tract, $[6,9,12]$ holding a significant competitive advantage over D614 strong enough that an airway culture with D614 and G614 in a 3:1 saw G614 overtake and gain an advantage of 1.2 over D614 within a day [9]. It was also associated with enhanced retention of infectivity under higher temperatures [9], though it should be noted that there has been no established positive association between D614G and increased disease severity [6,13].

\subsection{E484K}

E484K, an escape mutation, emerged from Brazil in the second half of 2020 and has increased in frequency since [14]. The change of glutamic acid to lysine elicits a positive charge from a previous negative charge and changes the branched structure of the functional group into a linear structure. It is responsible for the loss of an ion pair in the amino acid 31, a lysine in ACE2 [15], which is predicted to moderately increase ACE2 affinity. In-silico experiments have found that it enhances binding affinity with the ACE2 receptor [15-17] due to its heavy involvement in hydrogen bonding and salt bridges between the receptor and the RBD [17]. It also aids the virus in avoiding antibody neutralization, especially by convalescent and vaccine sera, requiring higher titers overall [18-20] and reducing plasma neutralization up to 10 fold in some instances [20]. In 
regards to $\mathrm{mAbs}$, E484K conferred increased resistance against multiple mAbs $[21,22]$. High resistance in particular to bamlanivimab and, to a lesser extent, casirivimab was developed [22], implying that most of the antibodies included $\mathrm{E} 484 \mathrm{~K}$ as an epitope and had the structure tightly fit the epitope via electrostatic interaction. E484K has been associated with reinfection after vaccination or recovery $[23,24]$.

\subsection{N501Y}

N501Y rose to prominence mainly around late September of 2020 along with the B.1.1.7 variant [25] and is associated primarily with an increase in ACE2 binding affinity and, resultantly, increased infectivity [26-30]. The change of asparagine to tyrosine increases hydrophobicity, the density of pi electrons, and the steric hindrance of the functional group. It leads to the virus having a lower dissociation constant (KD), meaning that the spike protein can stay attached to the ACE2 receptor more firmly for longer, leading to a greater chance of membrane fusion and cell entry $[15,27]$. Compared to the wild type (WT) RBD variant, the N501Y RBD had a 7.1 fold increase in affinity for ACE2 when measured using surface plasmon resonance [15]. This implies that hydrophobic, pi-pi, cation-pi interactions could enhance the binding to the ACE2 receptor or membrane for cellular penetration. Pseudovirus infection was observed to increase entry into human lung airway organoids to be N501Y was associated along with $\mathrm{K} 417 \mathrm{~N} / \mathrm{T}$ and E484K with an increase in binding affinity and, consequently, viral infectivity [28]. While N501Y does increase resistance to a number of specific mAbs such as COVA1-12 and CB6 [31,32], this is relatively insignificant $[32,33]$ for vaccination or treatment as it has "no pronounced effects on the neutralizing activity of convalescent plasma or sera from vaccinated individuals" [4]. This makes sense given that the N501Y mutation does not appear to significantly affect the spike protein's structure, leaving key neutralization epitopes adequately intact [34]. Interestingly, $\mathrm{N} 501 \mathrm{Y}$ seems to be in at least some ways complementary to E848K. A trial using pseudoviruses found that N501Y in combination with either E484K or K417N led to slightly disproportionately elevated infectivity [26].

\section{4. $\mathrm{K417N}$}

The $\mathrm{K} 417 \mathrm{~N}$ mutation is rather unusual because its effects on the virus are, as far as research so far has shown, mostly negative. The change from lysine to asparagine shifts the charge of the functional group from positive to neutral and decreases its length. It disrupts the salt bridge between the ACE2 receptor and the spike protein, leading to a decrease in binding energy by $1.48 \mathrm{kcal} / \mathrm{mol}$ [35]. Relative binding affinity with $\mathrm{K} 417 \mathrm{~N}$ alone is, therefore, lower than that of the WT, and the difference is even more pronounced when compared to an N501Y mutation variant [15]. This implies that the N417 mutation causes a loss in electrostatic attraction to the ACE2 receptor due to neutralized charge. It is also associated with a slight increase in neutralization resistance and some escape from neutralization by certain mAbs such as CB6 [26,35], though this is possibly an oversimplification; some data has shown evidence for the opposite, that the $\mathrm{K} 417 \mathrm{~N}$ mutation actually increases viral sensitivity to neutralization [36]. Given its unfavorable nature, the reasons for its selection by viral evolution are not well understood. It is hypothesized that the mutation was selected to resolve a vulnerable target in the WT RBD. K417 can form a salt bridge with glutamate/aspartate found in certain human antibodies, which would make it a key point for neutralization. The mutation, therefore, could be seen as evidence of the virus adapting under the pressure of human neutralizing mAbs [36]. With N501Y, the mutation was associated with increased lethality of disease [17]. K417N often appears with E484K and N501Y. This trio most notably increases infectivity and resistance to neutralization [26].

\subsection{L452R}

L452R is an S mutation of the RBD and is present in the VOC B.1.617.2. The change of leucine to arginine elicits change from a neutral charge to a positive charge, increased hydrophilicity, and a lengthening of the functional group. It provides numerous benefits for viral fitness and infectivity, increasing S protein stability and ACE2 affinity [37]. This implies that the elicited hydrogen bonding and electrostatic attraction with the ACE2 receptor compensate for the initial hydrophobic interaction. This increase in infectivity has been measured in pseudoviruses carrying the mutation entering human lung airway organoids to be 5.8 to 14.7 fold compared to pseudoviruses carrying D614G alone. [38]. L452R has been associated with decreased susceptibility to neutralization by vaccine and convalescent sera [37], with 2 and 4.0 to 6.7 -fold decreases in neutralizing titers, respectively, when in variant B.1.427/B.1.429 [38]. A novel variant originating from the B.1.362 lineage that carried L452R displayed a four-fold decrease in neutralization susceptibility to BNT162b2 (Pfizer) vaccine sera [39]. This implies that the antibodies included L452R as an epitope and had the structure that tightly fit the epitope via hydrophobic interaction. A study by McCallum et al. found that "The RBD L452R mutation reduced or abolished the neutralizing activity of 14 out of 35 RBD-specific monoclonal antibodies (mAbs), including three clinical-stage mAbs" [40]. 


\subsection{P681R}

P681R is a mutation not in the RBD but in the furin cleavage site in the VOC B.1.617.2 and is primarily associated with enhanced viral fitness. The change from proline to arginine elicits a change from a positive charge to a neutral charge, as well as increased hydrophilicity of the functional group. It is interesting to note that arginine residue could be cleaved by proteases and that $\mathrm{C}$-end arginine could be electrostatically attracted to the negative charge of the cell membrane, increasing cellular penetration efficacy. Binding to cells is made more efficient and rapid, which could account for B.1.617.2's positive association with greater viral loads, disease severity, and hospitalization [41]. This is also a potential reason that vaccine breakthrough cases have been observed in B.1.617.2 as opposed to the hypothesis that neutralization escape is the primary cause [42]. P681R has been associated with increased resistance to neutralizing antibodies [41], though more specific research in this area is at the moment lacking. This may be caused by the changed epitope structure of the cleaved spike protein, although P681R is not included in the epitope.

\section{VOCs}

\subsection{Alpha (B.1.1.7)}

The B.1.1.7 variant was first identified in September 2020 in the United Kingdom in Table 2 [43]. It is defined by 22 mutations, 9 of which are Spike (S) mutations [44]. The strain was one of the first that harbored the D614G mutation to be formally recognized as a VOC. The strain also contains a notable N501Y mutation, which is closely linked to the RBD and therefore is tied to infectivity and neutralization sensitivity. B.1.1.7 is commonly cited as having approximately a $50 \%$ greater infectivity compared to previous variants [45]. However, it should be noted that the estimated value ranges from 43-90\% [46-48]. B.1.1.7 RBD demonstrates 1.98 times greater binding to the ACE2 receptor when compared to the $\mathrm{Hu}-1$ strain that was originally identified in Wuhan and using microscale thermophoresis [49] has been calculated to have a dissociation constant $(\mathrm{KD}$, where lower values indicate stronger interaction) of $10.7 \mathrm{nM}$ according to Zhou et al. [50], which is a factor in its increased infectivity. The combination of D614G and N501Y induces a neutral charge and increased hydrophobicity of functional groups, which stabilizes the binding to the ACE2 receptor or cellular membrane for cell entrance via hydrophobic interaction. The variant has also been shown to possess increased airborne transmissibility [48]. B.1.1.7 shows mostly unchanged sensitivity to convalescent plasma or vaccine sera $[4,51,52]$, implying that its mutations mostly do not affect the epitope structure. It does show some resistance to neutralization by certain monoclonal antibodies (mAbs), which might use the epitope affected by the mutation, however [4,51]. Overall, while B.1.1.7 is more difficult to neutralize, it does not express significant escape from neutralization by convalescent sera, vaccine sera, and most mAbs.

\subsection{Beta (B.1.351)}

The B.1.351 variant was first identified around December of 2020 in South Africa [53]. It is characterized by 18 mutations, 8 of which are $\mathrm{S}$ mutations [54]. B.1.351 shares the $\mathrm{D} 614 \mathrm{G}, \mathrm{N} 501 \mathrm{Y}$, and, in cases where it is present in B.1.1.7, the E484K spike mutations with B.1.1.7. B.1.351 has been calculated to display increased infectivity [55] of

Table 2. Variants of Covid-19

\begin{tabular}{|c|c|c|c|c|c|}
\hline Lineage & Spike Mutations & RBD Mutations & Remarks on infectivity & $\begin{array}{l}\text { Sensitivity } \\
(\mathrm{mABs})\end{array}$ & $\begin{array}{l}\text { Sensitivity } \\
\text { (Sera) }\end{array}$ \\
\hline $\begin{array}{l}\text { B.1.1.7 } \\
\text { (Alpha) }\end{array}$ & $\begin{array}{l}\text { D614G, D1118H, A570D, } \\
\text { S982A, T716I, P681H, } \\
\text { N501Y, del69/70, del144/145 }\end{array}$ & N501Y, D614G & $\begin{array}{l}\text { Increased } \sim 50 \%[45-48] . \\
\text { ACE2 binding dissociation } \\
\text { constant (KD) of } 10.7 \mathrm{nM}[50] .\end{array}$ & $\begin{array}{l}\text { Reduced in some } \\
\text { cases }[4,52] .\end{array}$ & $\begin{array}{l}\text { No significant } \\
\text { change }[4,51,52]\end{array}$ \\
\hline $\begin{array}{l}\text { B.1.351 } \\
\text { (Beta) }\end{array}$ & $\begin{array}{l}\text { D614G, D80A, A701V, } \\
\text { D215G, K417N, N501Y, } \\
\text { E484K, del241/243 }\end{array}$ & $\begin{array}{l}\text { K417N,E484K, } \\
\text { N501Y, D614G }\end{array}$ & $\begin{array}{l}\text { Increased } \sim 50 \%[55,56] \text {. } \\
\text { KD } 4.0 \mathrm{nM}[50]\end{array}$ & $\begin{array}{l}\text { Reduced } \\
{[4,50,57,58] .}\end{array}$ & Reduced $[4,50,57]$. \\
\hline $\begin{array}{l}\text { B.1.617.2 } \\
\text { (Delta) }\end{array}$ & $\begin{array}{l}\text { D614G, P681R, T19R, } \\
\text { T478K, L452R, D950N, } \\
\text { E156G, del157/158, E484Q }\end{array}$ & $\begin{array}{l}\text { L452R, T478K, } \\
\text { E484Q, D614G }\end{array}$ & $\begin{array}{l}\text { Increased. Unclear exactly to } \\
\text { what extent. Speculations being } \\
\text { at } \sim 50 \% \text { compounding with } \\
\text { B.1.1.7 [2,61,62]. } \\
\text { KD } 1.4 \text { nM [61] }\end{array}$ & Reduced $[63,64]$. & Reduced [63-66]. \\
\hline $\begin{array}{l}\text { P.1 } \\
\text { (Gamma) }\end{array}$ & $\begin{array}{l}\text { D614G, V117HF, H655Y, } \\
\text { L18F, P26S, T20N, T1027I, } \\
\text { D138Y, N501Y, E484K, } \\
\text { K417T, R190S }\end{array}$ & $\begin{array}{l}\text { K417T, E484K, } \\
\text { N501Y, D614G }\end{array}$ & $\begin{array}{l}\text { Increased. Estimated to be } \\
\text { around } 2 \text {-fold from previous } \\
\text { variants }[68,70,71] . \\
\text { KD } 4.8 \mathrm{nM}[72]\end{array}$ & $\begin{array}{l}\text { Reduced } \\
{[57,58,73,74] .}\end{array}$ & Reduced [74]. \\
\hline
\end{tabular}

Mutations of particular note due to the attention received from the community, relevance to the RBD, or recurrence across lineages are bolded. 
approximately $50 \%$ compared to previous variants [56]. Increased infectivity might be caused by the same reasons as D614G and N501Y of B.1.1.7. B.1.351 has been calculated to have an affinity for ACE2 that is 2.7 fold higher than that of B.1.1.7, with a $\mathrm{KD}$ of $4.0 \mathrm{nM}$, according to Zhou et al. [50]. Unlike B.1.1.7, B.1.351 shows decidedly stronger resistance to neutralization by convalescent and post-vaccination sera $[4,50,57]$, as well as significantly reduced sensitivity to specific $\mathrm{mAbs}$, especially bamlanivimab and casirivimab [22,57,58]. B.1.351 showed widespread escape from neutralization by $\mathrm{mAbs}$ as well as reduced sensitivity to convalescent and vaccine sera. [4,50,57]. This implies that the combination of $\mathrm{K} 417 \mathrm{~N}$ and $\mathrm{E} 484 \mathrm{~K}$ in the epitope induces neutral charges and charge transition, which reduces electrostatic attractions and/or increases electrostatic repulsion with tightly-fitting antibodies.

\subsection{Delta (B.1.617.2)}

The B.1.617.2 variant was first documented around October of 2020 in India. It is characterized by around 24 mutations, 8 of which are S mutations [3], and is differentiated from B.1.617.1 by the presence of the mutations L452R, P681R, and T478K in its RBD [59]. It lacks the N501Y mutation, which makes B.1.617.2 unique among the four primary VOCs. It also lacks the vaccine escape mutation E484K possessed by B.1.351 and P.1 [60]. B.1.617.2 shows decidedly higher transmissibility with a greater affinity for the ACE2 receptor, $[2,61,62]$ with a calculated molecular dynamics equilibrated $\mathrm{KD}$ value of $1.4 \mathrm{nM}$ in comparison to the WT's KD of $4.0 \mathrm{nM}$ according to Khan et al. [61]. This might be caused by the combination of L452R, T478K, E484Q, D614G, and Q681R in the RBD. Interestingly, all mutations changed surface charges of $\mathrm{S}$ protein towards positivity. Therefore, the mutated B.1.617.1 S protein could interact with negatively charged cellular membranes and enhance the cellular uptake of viruses. Among them, L452R and T478K change the spike from a neutral to a positive charge, which might induce hydrogen bonding or electrostatic attraction. E484Q and D614G elicit change from a negative charge to a neutral charge. D614G increased the affinity for the ACE2 receptor by the explanation in chapter 2.1. On the other hand, E484Q may only minimally affect the affinity by forming hydrogen bonds to compensate for electrostatic attraction. Finally, cleaved P681R might interact with the cellular membrane and improve cellular uptake efficacy. Primary studies found it to be $64 \%$ more infectious than B.1.1.7 [62]. According to the CDC, B.1.617.2 shows double the infectivity of previous variants [2]. Sensitivity to mAbs was reduced [63], especially for Bamlanivimab [64]. B.1.617.2's sensitivity to vaccines and convalescent sera was also reduced, showing enhanced resistance to neutralization, with AstraZeneca sera's effectiveness (67\% with two doses) being reduced more than that of Pfizer-n (88\% with two doses) [63-66]. The difference in vaccine effectiveness between B.1.1.7 and B.1.617.2 was more notable in the single-dose stage, with Pfizer-n showing first-dose-effectiveness against B.1.1.7 and B.1.617.2 of $47.5 \%$ and $35.6 \%$ respectively, compared to second-dose effectiveness of $93.7 \%$ and $88.0 \%$, respectively [66]. In addition, B.1.617.2 shows an association with greater illness severity [67]. This implies that the combination of L452R, T478K, and E484Q in the epitope induces charge transitions which reduce electrostatic attractions and/or increase electrostatic repulsion with tightly-fitting antibodies.

\subsection{Gamma (P.1)}

The P.1 variant was first identified in January of 2021 in Brazil (though samples containing the variant were collected in December the year before and may have been in circulation for months prior) [68]. It is characterized by 24 mutations, 12 of which are S mutations [69]. P.1 shares the E484K, N501Y, and D614G spike mutations with B.1.351, only $\mathrm{K} 417 \mathrm{~T}$ and $\mathrm{H} 655 \mathrm{Y}$ are different from $\mathrm{K} 417 \mathrm{~N}$ of B.1.351. Its infectivity increase is potentially double that of other variants as its reproductive number value was 2.2 times that of B.1.1.28, a parental lineage circulating around the same time as P.1 [68,70,71]. It can therefore be postulated that the increase in infectivity of P.1 over B.1.351 is not due to E484K, N501Y, and D614G but K417T and H655Y. K417T changes lysine to threonine in the $\mathrm{S}$ protein, which causes the formation of a neutral charge, hydrogen bonding, and reduced steric hindrance. H655Y changes histidine to tyrosine which induces a hydrophobic interaction with the human cellular membrane. The synergistic effect of K417T and H655Y may enhance virus infectivity. P.1 was calculated to have a $\mathrm{KD}$ of $4.8 \mathrm{nM}$, according to Dejnirattisai et al. [72].

P.1 is less sensitive to multiple mAbs [72], notably avoiding neutralization by the Emergency Use Authorized mAbs casirivimab, bamlanivimab, and etesevimab $[57,58$, 73,74]. The patterns in which P.1 resisted or escaped neutralization were similar to that of B.1.351. This is in alignment with the fact that the two variants share many of their RBD mutations, though it should be noted that differences do exist [74]. P.1 is, as expected, also less sensitive to neutralization by convalescent and vaccine sera [74] to a degree comparable to B.1.1.7 [72] and less severe than in B.1.351 [4]. This implies that the combination of $\mathrm{K} 417 \mathrm{~T}$ and $\mathrm{E} 484 \mathrm{~K}$ in the epitope induces neutral charges and charge transition, which reduces electrostatic attractions or increases electrostatic repulsion with tightly-fitting antibodies. 


\subsection{Other variants}

Several other variants of interest (VOI), primarily B.1.621 (mu) and C.37 (lambda), are regarded as possessing the potential to affect the pandemic significantly. Genetic changes are predicted or known to affect virus characteristics and identified to cause significant community transmission. B.1.621 (mu) variant was first detected in Colombia in January 2021 and designated by the WHO as a variant of interest on Aug. 30, 2021. The WHO mentioned that B.1.621 has mutations that indicate a risk of resistance to the current vaccines [75]. B.1.621 possesses the spike mutations T95I, Y144S, Y145N, R346K, E484K, N501Y, D614G, P681H, and D950N. E484K and N501Y are located in RBM. The C.37 (lambda) variant was first detected in Peru in August 2020 and designated by the WHO as a variant of interest on Jun. 14, 2021. Although C.37 was reported to be more infectious and resistant to neutralizing antibodies than the B.1.1.7 and P.1 variants [76], further research is necessary to understand its properties. C.37 possesses the spike mutations G75V, T76I, $4246-252$, L452Q, F490S, D614G, and T859N. Among them, L452Q and F490S are located in RBM. Also, the variants under monitoring (VUM) are R.1, B.1.466.2, B1.1.318, B.1.1.519, C.36.3, B.1.214.2, B.1.427 with B.1.429 (epsilon), B.1.1.523, B.1.619, B.1.620, C.1.2, B.1.617.1 (kappa), B.1.526 (lota), B.1.525 (eta), and B.1.630. VUMs are variants that have the potential to be problematic in the future, but whose phenotypic or epidemiological impacts are still unclear.

\section{Patterns and Interactions of Mutations}

It should be noted that these mutations do not act in isolation from each other. The sophisticated structural changes that mutations may incur allow them to affect each other $[18,77]$. Examples of associations that support this include E484K and N501Y being more effective in allowing viruses to develop elevated infectivity when together [26], and the trio of $\mathrm{E} 484 \mathrm{~K}, \mathrm{~N} 501 \mathrm{Y}$, and $\mathrm{K} 417 \mathrm{~N}$ together conferring greater neutralization resistance than they would individually [16,78]. A specific example of this in action is the aforementioned three together being responsible for moderately increased resistance to neutralization by convalescent and vaccine sera (specifically the Pfizer vaccine) [26]. Some mutations are epistatic, in other words, the expression of one depends on the presence of one or more other mutations, such as in the case of N501Y and Q498R [79]. While the occurrence of mutations is mostly random, the selection for mutations is not. It has been shown that, in some cases, mutations develop under the selective pressure of the human immune response (such as in the case of $\mathrm{K} 417 \mathrm{~N})[80,81]$.

\section{Conclusions}

In this article, we present an overview of the current state of our understanding on the major variants of SARS COV2. In addition to the primary properties of each VOC, we also presented a closer look at each mutation in the highly important RBD of the S protein, identifying the most notable changes they entailed. Variants sharing key mutations in the spike protein tended to display similar changes in properties, such as with resistance to neutralization in B.1.351 and P.1.

In Fig. 1, mutation sites were mostly located on the surface of the receptor-binding domain (RBD), especially in the receptor-binding motif (RBM, red box in Fig. 1D). Therefore, it is highly probable that future mutations will occur in the RBM. Moreover, mutations affecting contagiousness are favorable for receptor binding, such as increased hydrophobic interaction, hydrogen bonding, and ion-pair interaction. Also, positively charged lysine or arginine near the RBM changed to a threonine will neutralize the charge and increase hydrogen bonding for membrane penetration. On the other hand, therapeutic antibodies need to be produced using the epitopes with various mutation combinations of the RBM or conserved regions related to $\mathrm{RBD}$ opening for the optimal binding capacity.

Many of these mutations are quite recent developments and require further study, especially those in emerging Variants of Interest (VOIs) and VOCs. The mechanisms by which mutations affect proteins are interlinked and often complex. Mutations can have compound effects, and one can even boost the effectiveness of the other. Certain mutations commonly appear together and confer a combination such as B.1.617.2, and how they affect each other is required for a better, more comprehensive understanding. Given the slight predictability in the selection of mutations under pressure from the immune system and neutralization, it is not infeasible to suggest that a systemic consideration of possible mutations with an understanding of their individual properties (with emphasis on escape mutations, as prior knowledge of these gives far more opportunities for prophylaxis) is possible. Understanding the correlation between present virus variants and mutations could be applied to in-silico modeling in order to anticipate upcoming variants. This understanding could also be applied to diagnose infectivity, disease severity, and lethality by variant identification. Moreover, it could be used to design antibody epitopes for efficient variant neutralization and prepare new antibodies for the incoming variants. Ultimately, we expect this understanding will prove a valuable resource in winning the war against COVID-19. 


\section{Author Contributions}

Conceptualization, writing-original draft preparation G.P., writing-review and editing, B.H. All authors have read and agreed to the published version of the manuscript.

\section{Acknowledgment}

Special thanks to Dr. Jihee Park, who produced Fig. 1.

\section{Funding}

Not applicable.

\section{Data Availability Statement}

Not applicable.

\section{Conflicts of Interests}

The authors declare no conflict of interest.

\section{Informed Consent}

Neither ethical approval nor informed consent was required for this study.

\section{References}

1. Cucinotta, D. and M. Vanelli (2020) WHO declares COVID-19 a pandemic. Acta Biomed. 91: 157-160.

2. CDC, Coronavirus Disease 2019 (COVID-19 delta-variant). https://www.cdc.gov.

3. Outbreak.info, B.1.617.2 Lineage Report. https://outbreak.info/ situation-reports?pango=B.1.617.2.

4. Wang, P., M. S. Nair, L. Liu, S. Iketani, Y. Luo, Y. Guo, M. Wang, J. Yu, B. Zhang, P. D. Kwong, B. S. Graham, J. R. Mascola, J. Y. Chang, M. T. Yin, M. Sobieszczyk, C. A. Kyratsous, L. Shapiro, Z. Sheng, Y. Huang, and D. D. Ho (2021) Antibody resistance of SARS-CoV-2 variants B.1.351 and B.1.1.7. Nature. 593: 130-135.

5. Hodcroft, E. B., D. B. Domman, D. J. Snyder, K. Y. Oguntuyo, M. Van Diest, K. H. Densmore, K. C. Schwalm, J. Femling, J. L. Carroll, R. S. Scott, M. M. Whyte, M. W. Edwards, N. C. Hull, C. G. Kevil, J. A. Vanchiere, B. Lee, D. L. Dinwiddie, V. S. Cooper, and J. P. Kamil (2021) Emergence in late 2020 of multiple lineages of SARS-CoV-2 spike protein variants affecting amino acid position 677. medRxiv. 2021.02.12.21251658.

6. Korber, B., W. M. Fischer, S. Gnanakaran, H. Yoon, J. Theiler, W. Abfalterer, N. Hengartner, E. E. Giorgi, T. Bhattacharya, B.
Foley, K. M. Hastie, M. D. Parker, D. G. Partridge, C. M. Evans, T. M. Freeman, T. I. de Silva, A. Angyal, R. L. Brown, L. Carrilero, L. R. Green, D. C. Groves, K. J. Johnson, A. J. Keeley, B. B. Lindsey, P. J. Parsons, M. Raza, S. Rowland-Jones, N. Smith, R. M. Tucker, D. Wang, M. D. Wyles, C. McDanal, L. G. Perez, H. Tang, A. Moon-Walker, S. P. Whelan, C. C. LaBranche, E. O. Saphire, and D. C. Montefiori (2020) Tracking changes in SARS-CoV-2 spike: Evidence that D614G increases infectivity of the COVID-19 virus. Cell. 182: 812-827.e19.

7. Hou, Y. J., S. Chiba, P. Halfmann, C. Ehre, M. Kuroda, K. H. Dinnon 3rd, S. R. Leist, A. Schäfer, N. Nakajima, K. Takahashi, R. E. Lee, T. M. Mascenik, R. Graham, C. E. Edwards, L. V. Tse, K. Okuda, A. J. Markmann, L. Bartelt, A. de Silva, D. M. Margolis, R. C. Boucher, S. H. Randell, T. Suzuki, L. E. Gralinski, Y. Kawaoka, and R. S. Baric (2020) SARS-CoV-2 D614G variant exhibits efficient replication ex vivo and transmission in vivo. Science. 370: 1464-1468.

8. Ozono, S., Y. Zhang, H. Ode, K. Sano, T. S. Tan, K. Imai, K. Miyoshi, S. Kishigami, T. Ueno, Y. Iwatani, T. Suzuki, and K. Tokunaga (2021) SARS-CoV-2 D614G spike mutation increases entry efficiency with enhanced ACE2-binding affinity. Nat. Commun. 12: 848.

9. Plante, J. A., Y. Liu, J. Liu, H. Xia, B. A. Johnson, K. G. Lokugamage, X. Zhang, A. E. Muruato, J. Zou, C. R. FontesGarfias, D. Mirchandani, D. Scharton, J. P. Bilello, Z. Ku, Z. An, B. Kalveram, A. N. Freiberg, V. D. Menachery, X. Xie, K. S. Plante, S. C. Weaver, and P. Y. Shi (2021) Spike mutation D614G alters SARS-CoV-2 fitness. Nature. 592: 116-121.

10. Mansbach, R. A., S. Chakraborty, K. Nguyen, D. C. Montefiori, B. Korber, and S. Gnanakaran (2021) The SARS-CoV-2 spike variant D614G favors an open conformational state. Sci. Adv. 7: eabf3671.

11. Weissman, D., M. G. Alameh, T. de Silva, P. Collini, H. Hornsby, R. Brown, C. C. LaBranche, R. J. Edwards, L. Sutherland, S. Santra, K. Mansouri, S. Gobeil, C. McDanal, N. Pardi, N. Hengartner, P. J. C. Lin, Y. Tam, P. A. Shaw, M. G. Lewis, C. Boesler, U. Şahin, P. Acharya, B. F. Haynes, B. Korber, and D. C. Montefiori (2021) D614G spike mutation increases SARS CoV-2 susceptibility to neutralization. Cell Host Microbe. 29: 23-31.e4.

12. Long, S. W., R. J. Olsen, P. A. Christensen, D. W. Bernard, J. J. Davis, M. Shukla, M. Nguyen, M. O. Saavedra, P. Yerramilli, L. Pruitt, S. Subedi, H. C. Kuo, H. Hendrickson, G. Eskandari, H. A. T. Nguyen, J. H. Long, M. Kumaraswami, J. Goike, D. Boutz, J. Gollihar, J. S. McLellan, C. W. Chou, K. Javanmardi, I. J. Finkelstein, and J. M. Musser (2020) Molecular architecture of early dissemination and massive second wave of the SARS-CoV2 virus in a major metropolitan area. mBio. 11: e02707-20.

13. Volz, E., V. Hill, J. T. McCrone, A. Price, D. Jorgensen, Á. O'Toole, J. Southgate, R. Johnson, B. Jackson, F. F. Nascimento, S. M. Rey, S. M. Nicholls, R. M. Colquhoun, A. da Silva Filipe, J. Shepherd, D. J. Pascall, R. Shah, N. Jesudason, K. Li, R. Jarrett, N. Pacchiarini, M. Bull, L. Geidelberg, I. Siveroni, I. Goodfellow, N. J. Loman, O. G. Pybus, D. L. Robertson, E. C. Thomson, A. Rambaut, and T. R. Connor (2021) Evaluating the Effects of SARS-CoV-2 spike mutation D614G on transmissibility and pathogenicity. Cell. 184: 64-75.

14. Ferrareze, P. A. G., V. B. Franceschi, A. de Menezes Mayer, G. D. Caldana, R. A. Zimerman, and C. E. Thompson (2021) E484K as an innovative phylogenetic event for viral evolution: Genomic analysis of the E484K spike mutation in SARS-CoV-2 lineages from Brazil. Infect. Genet. Evol. 93: 104941.

15. Laffeber, C., K. de Koning, R. Kanaar, and J. H. G. Lebbink (2021) Experimental evidence for enhanced receptor binding by rapidly spreading SARS-CoV-2 variants. J. Mol. Biol. 433: 167058.

16. Nelson, G., O. Buzko, P. Spilman, K. Niazi, S. Rabizadeh, and P. Soon-Shiong (2021) Molecular dynamic simulation reveals 
E484K mutation enhances spike RBD-ACE2 affinity and the combination of E484K, K417N and N501Y mutations (501Y.V2 variant) induces conformational change greater than N501Y mutant alone, potentially resulting in an escape mutant. bioRxiv. 2021.01.13.426558.

17. Khan, A., T. Zia, M. Suleman, T. Khan, S. S. Ali, A. A. Abbasi, A. Mohammad, and D. Q. Wei (2021) Higher infectivity of the SARS-CoV-2 new variants is associated with K417N/T, E484K, and N501Y mutants: An insight from structural data. J. Cell Physiol. 236: 7045-7057.

18. Alenquer, M., F. Ferreira, D. Lousa, M. Valério, M. MedinaLopes, M. L. Bergman, J. Gonçalves, J. Demengeot, R. B. Leite, J. Lilue, Z. Ning, C. Penha-Gonçalves, H. Soares, C. M. Soares, and M. J. Amorim (2021) Signatures in SARS-CoV-2 spike protein conferring escape to neutralizing antibodies. PLoS Pathog. 17: e1009772.

19. Jangra, S., C. Ye, R. Rathnasinghe, D. Stadlbauer, F. Krammer, V. Simon, L. Martinez-Sobrido, A. Garcia-Sastre, and M. Schotsaert (2021) The E484K mutation in the SARS-CoV-2 spike protein reduces but does not abolish neutralizing activity of human convalescent and post-vaccination sera. medRxiv. 2021.01.26. 21250543.

20. Greaney, A. J., A. N. Loes, K. H. D. Crawford, T. N. Starr, K. D. Malone, H. Y. Chu, and J. D. Bloom (2021) Comprehensive mapping of mutations in the SARS-CoV-2 receptor-binding domain that affect recognition by polyclonal human plasma antibodies. Cell Host Microbe. 29: 463-476.e6.

21. Baum, A., B. O. Fulton, E. Wloga, R. Copin, K. E. Pascal, V. Russo, S. Giordano, K. Lanza, N. Negron, M. Ni, Y. Wei, G. S. Atwal, A. J. Murphy, N. Stahl, G. D. Yancopoulos, and C. A. Kyratsous (2020) Antibody cocktail to SARS-CoV-2 spike protein prevents rapid mutational escape seen with individual antibodies. Science. 369: 1014-1018.

22. Widera, M., A. Wilhelm, S. Hoehl, C. Pallas, N. Kohmer, T. Wolf, H. F. Rabenau, V. M. Corman, C. Drosten, M. J. G. T. Vehreschild, U. Goetsch, R. Gottschalk, and S. Ciesek (2021) Limited neutralization of authentic severe acute respiratory syndrome coronavirus 2 variants carrying E484K in vitro. J. Infect. Dis. 224: 1109-1114.

23. Mostafa, H. H., C. H. Luo, C. P. Morris, M. Li, N. J. Swanson, A. Amadi, N. Gallagher, and A. Pekosz (2021) SARS-CoV-2 infections in MRNA vaccinated individuals are biased for viruses encoding spike E484K and associated with reduced infectious virus loads that correlate with respiratory antiviral $\operatorname{IgG}$ levels. medRxiv. 2021.07.05.21259105.

24. Nonaka, C. K. V., M. M. Franco, T. Gräf, C. A. de Lorenzo Barcia, R. N. de Ávila Mendonça, K. A. F. de Sousa, L. M. C. Neiva, V. Fosenca, A. V. A. Mendes, R. S. de Aguiar, M. Giovanetti, and B. S. de Freitas Souza (2021) Genomic evidence of SARS-CoV-2 reinfection involving E484K spike mutation, Brazil. Emerg. Infect. Dis. 27: 1522-1524.

25. Leung, K., M. H. Shum, G. M. Leung, T. T. Lam, and J. T. Wu (2021) Early transmissibility assessment of the N501Y mutant strains of SARS-CoV-2 in the United Kingdom, October to November 2020. Euro Surveill. 26: 2002106.

26. Kuzmina, A., Y. Khalaila, O. Voloshin, A. Keren-Naus, L. Boehm-Cohen, Y. Raviv, Y. Shemer-Avni, E. Rosenberg, and R. Taube (2021) SARS-CoV-2 spike variants exhibit differential infectivity and neutralization resistance to convalescent or postvaccination sera. Cell Host Microbe. 29: 522-528.e2.

27. Tian, F., B. Tong, L. Sun, S. Shi, B. Zheng, Z. Wang, X. Dong, and P. Zheng (2021) N501Y mutation of spike protein in SARSCoV-2 strengthens its binding to receptor ACE2. Elife. 10: e69091.

28. Starr, T. N., A. J. Greaney, S. K. Hilton, D. Ellis, K. H. D. Crawford, A. S. Dingens, M. J. Navarro, J. E. Bowen, M. A. Tortorici, A. C. Walls, N. P. King, D. Veesler, and J. D. Bloom
(2020) Deep mutational scanning of SARS-CoV-2 receptor binding domain reveals constraints on folding and ACE2 binding. Cell. 182: 1295-1310.

29. Santos, J. C. and G. A. Passos (2021) The high infectivity of SARS-CoV-2 B.1.1.7 is associated with increased interaction force between spike-ACE2 caused by the viral N501Y mutation. bioRxiv. 2020.12.29.424708.

30. Ali, F., A. Kasry, and M. Amin (2021) The new SARS-CoV-2 strain shows a stronger binding affinity to ACE2 due to N501Y mutant. Med. Drug Discov. 10: 100086.

31. Rees-Spear, C., L. Muir, S. A. Griffith, J. Heaney, Y. Aldon, J. L. Snitselaar, P. Thomas, C. Graham, J. Seow, N. Lee, A. Rosa, C. Roustan, C. F. Houlihan, R. W. Sanders, R. K. Gupta, P. Cherepanov, H. J. Stauss, E. Nastouli, SAFER Investigators, K. J. Doores, M. J. van Gils, and L. E. McCoy (2021) The effect of spike mutations on SARS-CoV-2 neutralization. Cell Rep. 34: 108890.

32. Cheng, L., S. Song, B. Zhou, X. Ge, J. Yu, M. Zhang, B. Ju, and Z. Zhang (2021) Impact of the N501Y substitution of SARSCoV-2 spike on neutralizing monoclonal antibodies targeting diverse epitopes. Virol. J. 18: 87.

33. Rathnasinghe, R., S. Jangra, A. Cupic, C. Martínez-Romero, L. C. F. Mulder, T. Kehrer, S. Yildiz, A. Choi, I. Mena, J. De Vrieze, S. Aslam, D. Stadlbauer, D. A. Meekins, C. D. McDowell, V. Balaraman, J. A. Richt, B. G. De Geest, L. Miorin, F. Krammer, V. Simon, A. García-Sastre, and M. Schotsaert (2021) The N501Y mutation in SARS-CoV-2 spike leads to morbidity in obese and aged mice and is neutralized by convalescent and postvaccination human sera. medRxiv. 2021.01.19.21249592.

34. Zhu, X., D. Mannar, S. S. Srivastava, A. M. Berezuk, J. P. Demers, J. W. Saville, K. Leopold, W. Li, D. S. Dimitrov, K. S. Tuttle, S. Zhou, S. Chittori, and S. Subramaniam (2021) Cryoelectron microscopy structures of the N501Y SARS-CoV-2 spike protein in complex with ACE2 and 2 potent neutralizing antibodies. PLoS Biol. 19: e3001237.

35. Luan, B. and T. Huynh (2021) Insights into SARS-CoV-2's mutations for evading human antibodies: Sacrifice and survival. J. Med. Chem. doi: 10.1021/acs.jmedchem.1c00311.

36. Li, Q., J. Nie, J. Wu, L. Zhang, R. Ding, H. Wang, Y. Zhang, T. Li, S. Liu, M. Zhang, C. Zhao, H. Liu, L. Nie, H. Qin, M. Wang, Q. Lu, X. Li, J. Liu, H. Liang, Y. Shi, Y. Shen, L. Xie, L. Zhang, X. Qu, W. Xu, W. Huang, and Y. Wang (2021) SARS-CoV-2 501Y.V2 variants lack higher infectivity but do have immune escape. Cell. 184: 2362-2371.

37. Motozono, C., M. Toyoda, J. Zahradnik, A. Saito, H. Nasser, T. S. Tan, I. Ngare, I. Kimura, K. Uriu, Y. Kosugi, Y. Yue, R. Shimizu, J. Ito, S. Torii, A. Yonekawa, N. Shimono, Y. Nagasaki, R. Minami, T. Toya, N. Sekiya, T. Fukuhara, Y. Matsuura, G. Schreiber, T. Ikeda, S. Nakagawa, T. Ueno, and K. Sato (2021) SARS-CoV-2 spike L452R variant evades cellular immunity and increases infectivity. Cell Host Microbe. 29: 1124-1136.e11.

38. Deng, X., M. A. Garcia-Knight, M. M. Khalid, V. Servellita, C. Wang, M. K. Morris, A. Sotomayor-González, D. R. Glasner, K. R. Reyes, A. S. Gliwa, N. P. Reddy, C. Sanchez San Martin, S. Federman, J. Cheng, J. Balcerek, J. Taylor, J. A. Streithorst, S. Miller, B. Sreekumar, P. Y. Chen, U. Schulze-Gahmen, T. Y. Taha, J. M. Hayashi, C. R. Simoneau, G. R. Kumar, S. McMahon, P. V. Lidsky, Y. Xiao, P. Hemarajata, N. M. Green, A. Espinosa, C. Kath, M. Haw, J. Bell, J. K. Hacker, C. Hanson, D. A. Wadford, C. Anaya, D. Ferguson, P. A. Frankino, H. Shivram, L. F. Lareau, S. K. Wyman, M. Ott, R. Andino, and C. Y. Chiu (2021) Transmission, infectivity, and neutralization of a spike L452R SARS-CoV-2 variant. Cell. 184: 3426-3439.e8.

39. Mor, O., M. Mandelboim, S. Fleishon, E. Bucris, D. Bar-Ilan, M. Linial, I. Nemet, L. Kliker, Y. Lustig, E. S. Mendelson, and N. S. Zuckerman (2021) The rise and fall of a local SARS-CoV-2 
variant with the spike protein mutation L452R. Vaccines (Basel). 9: 937.

40. McCallum, M., J. Bassi, A. De Marco, A. Chen, A. C. Walls, J. Di Iulio, M. A. Tortorici, M. J. Navarro, C. Silacci-Fregni, C. Saliba, K. R. Sprouse, M. Agostini, D. Pinto, K. Culap, S. Bianchi, S. Jaconi, E. Cameroni, J. E. Bowen, S. W. Tilles, M. S. Pizzuto, S. B. Guastalla, G. Bona, A. F. Pellanda, C. Garzoni, W. C. Van Voorhis, L. E. Rosen, G. Snell, A. Telenti, H. W. Virgin, L. Piccoli, D. Corti, and D. Veesler (2021) SARS-CoV-2 immune evasion by the B.1.427/B.1.429 variant of concern. Science. 373: 648-654.

41. Saito, A., T. Irie, R. Suzuki, T. Maemura, H. Nasser, K. Uriu, Y. Kosugi, K. Shirakawa, K. Sadamasu, I. Kimura, J. Ito, J. Wu, K. Iwatsuki-Horimoto, M. Ito, S. Yamayoshi, S. Ozono, E. P. Butlertanaka, Y. L. Tanaka, R. Shimizu, K. Shimizu, K. Yoshimatsu, R. Kawabata, T. Sakaguchi, K. Tokunaga, I. Yoshida, H. Asakura, M. Nagashima, Y. Kazuma, R. Nomura, Y. Horisawa, K. Yoshimura, A. Takaori-Kondo, M. Imai, The Genotype to Phenotype Japan (G2P-Japan) Consortium, S. Nakagawa, T. Ikeda, T. Fukuhara, Y. Kawaoka, and K. Sato (2021) SARS-CoV-2 spike P681R mutation, a hallmark of the delta variant, enhances viral fusogenicity and pathogenicity. bioRxiv. 2021.06.17.448820.

42. Liu, Y., J. Liu, B. A. Johnson, H. Xia, Z. Ku, C. Schindewolf, S. G. Widen, Z. An, S. C. Weaver, V. D. Menachery, X. Xie, and P. Y. Shi (2021) Delta spike P681R mutation enhances SARS-CoV2 fitness over alpha variant. bioRxiv. 2021.08.12.456173.

43. Higgins-Dunn, N. (2020) The U.K. has identified a new Covid19 strain that spreads more quickly. Here's what they know. https://www.cnbc.com.

44. Outbreak.info, B.1.1.7 Lineage Report. https://outbreak.info/ situation-reports?pango=B.1.1.7.

45. Chand, M., S. Hopkins, G. Dabrera, C. Achison, W. Barclay, N. Ferguson, E. Volz, N. Loman, A. Rambaut, and J. Barrett (2020) Investigation of novel SARS-COV-2 variant: Variant of concern 202012/01. Public Health England 21.

46. Davies, N. G., S. Abbott, R. C. Barnard, C. I. Jarvis, A. J. Kucharski, J. D. Munday, C. A. B. Pearson, T. W. Russell, D. C. Tully, A. D. Washburne, T. Wenseleers, A. Gimma, W. Waites, K. L. M. Wong, K. van Zandvoort, J. D. Silverman, CMMID COVID-19 Working Group, COVID-19 Genomics UK (COGUK) Consortium, K. Diaz-Ordaz, R. Keogh, R. M. Eggo, S. Funk, M. Jit, K. E. Atkins, and W. J. Edmunds (2021) Estimated transmissibility and impact of SARS-CoV-2 lineage B.1.1.7 in England. medRxiv. 372: eabg3055.

47. Volz, E., S. Mishra, M. Chand, J. C. Barrett, R. Johnson, L. Geidelberg, W. R. Hinsley, D. J. Laydon, G. Dabrera, Á. O'Toole, R. Amato, M. Ragonnet-Cronin, I. Harrison, B. Jackson, C. V. Ariani, O. Boyd, N. J. Loman, J. T. McCrone, S. Gonçalves, D. Jorgensen, R. Myers, V. Hill, D. K. Jackson, K. Gaythorpe, N. Groves, J. Sillitoe, D. P. Kwiatkowski, The COVID-19 Genomics UK (COG-UK) consortium, S. Flaxman, O. Ratmann, S. Bhatt, S. Hopkins, A. Gandy, A. Rambaut, and N. M. Ferguson (2021) Assessing transmissibility of SARS-CoV-2 lineage B.1.1.7 in England. Nature. 593: 266-269.

48. Port, J. R., C. K. Yinda, V. A. Avanzato, J. E. Schulz, M. G. Holbrook, N. van Doremalen, C. Shaia, R. J. Fischer, and V. J. Munster (2021) Increased aerosol transmission for B.1.1.7 (alpha variant) over lineage a variant of SARS-CoV-2. bioRxiv. 2021.07.26.453518.

49. Ramanathan, M., I. D. Ferguson, W. Miao, and P. A. Khavari (2021) SARS-CoV-2 B.1.1.7 and B.1.351 spike variants bind human ACE2 with increased affinity. Lancet Infect. Dis. 21: 1070.

50. Zhou, D., W. Dejnirattisai, P. Supasa, C. Liu, A. J. Mentzer, H. M. Ginn, Y. Zhao, H. M. E. Duyvesteyn, A. Tuekprakhon, R. Nutalai, B. Wang, G. C. Paesen, C. Lopez-Camacho, J. Slon-
Campos, B. Hallis, N. Coombes, K. Bewley, S. Charlton, T. S. Walter, D. Skelly, S. F. Lumley, C. Dold, R. Levin, T. Dong, A. J. Pollard, J. C. Knight, D. Crook, T. Lambe, E. Clutterbuck, S. Bibi, A. Flaxman, M. Bittaye, S. Belij-Rammerstorfer, S. Gilbert, W. James, M. W. Carroll, P. Klenerman, E. Barnes, S. J. Dunachie, E. E. Fry, J. Mongkolsapaya, J. Ren, D. I. Stuart, and G. R. Screaton (2021) Evidence of escape of SARS-CoV-2 variant B.1.351 from natural and vaccine-induced sera. Cell. 184: 2348-2361

51. Emary, K. R. W., T. Golubchik, P. K. Aley, C. V. Ariani, B. Angus, S. Bibi, B. Blane, D. Bonsall, P. Cicconi, S. Charlton, E. A. Clutterbuck, A. M. Collins, T. Cox, T. C. Darton, C. Dold, A. D. Douglas, C. J. A. Duncan, K. J. Ewer, A. Flaxman, S. N. Faust, D. M. Ferreira, S. Feng, A. Finn, P. M. Folegatti, M. Fuskova, E. Galiza, A. L. Goodman, C. M. Green, C. A. Green, M. Greenland, B. Hallis, P. T. Heath, J. Hay, H. C. Hill, D. Jenkin, S. Kerridge, R. Lazarus, V. Libri, P. J. Lillie, C. Ludden, N. G. Marchevsky, A. M. Minassian, A. C. McGregor, Y. F. Mujadidi, D. J. Phillips, E. Plested, K. M. Pollock, H. Robinson, A. Smith, R. Song, M. D. Snape, R. K. Sutherland, E. C. Thomson, M. Toshner, D. P. J. Turner, J. Vekemans, T. L. Villafana, C. J. Williams, A. V. S. Hill, T. Lambe, S. C. Gilbert, M. Voysey, M. N. Ramasamy, A. J. Pollard, The COVID-19 Genomics UK (COG-UK) consortium, and the Oxford COVID Vaccine Trial Group (2021) Efficacy of ChAdOx1 NCoV-19 (AZD1222) vaccine against SARS-CoV-2 VOC 202012/01 (B.1.1.7). http://dx.doi.org/10.2139/ssrn.3779160.

52. Supasa, P., D. Zhou, W. Dejnirattisai, C. Liu, A. J. Mentzer, H. M. Ginn, Y. Zhao, H. M. E. Duyvesteyn, R. Nutalai, A. Tuekprakhon, B. Wang, G. C. Paesen, J. Slon-Campos, C. LópezCamacho, B. Hallis, N. Coombes, K. R. Bewley, S. Charlton, T. S. Walter, E. Barnes, S. J. Dunachie, D. Skelly, S. F. Lumley, N. Baker, I. Shaik, H. E. Humphries, K. Godwin, N. Gent, A. Sienkiewicz, C. Dold, R. Levin, T. Dong, A. J. Pollard, J. C. Knight, P. Klenerman, D. Crook, T. Lambe, E. Clutterbuck, S. Bibi, A. Flaxman, M. Bittaye, S. Belij-Rammerstorfer, S. Gilbert, D. R. Hall, M. A. Williams, N. G. Paterson, W. James, M. W. Carroll, E. E. Fry, J. Mongkolsapaya, J. Ren, D. I. Stuart, and G. R. Screaton (2021) Reduced neutralization of SARS-CoV-2 B.1.1.7 variant by convalescent and vaccine sera. Cell 184: 22012211.

53. Tegally, H., E. Wilkinson, R. J. Lessells, J. Giandhari, S. Pillay, N. Msomi, K. Mlisana, J. N. Bhiman, A. von Gottberg, S. Walaza, V. Fonseca, M. Allam, A. Ismail, A. J. Glass, S. Engelbrecht, G. Van Zyl, W. Preiser, C. Williamson, F. Petruccione, A. Sigal, I. Gazy, D. Hardie, N. Hsiao, D. Martin, D. York, D. Goedhals, E. J. San, M. Giovanetti, J. Lourenço, L. C. J. Alcantara, and T. de Oliveira (2021) Sixteen novel lineages of SARS-CoV-2 in South Africa. Nat. Med. 27: 440-446.

54. Outbreak.info, B.1.351 Lineage Report. https://outbreak.info/ situation-reports?pango=B.1.351.

55. Tegally, H., E. Wilkinson, M. Giovanetti, A. Iranzadeh, V. Fonseca, J. Giandhari, D. Doolabh, S. Pillay, E. J. San, N. Msomi, K. Mlisana, A. von Gottberg, S. Walaza, M. Allam, A. Ismail, T. Mohale, A. J. Glass, S. Engelbrecht, G. Van Zyl, W. Preiser, F. Petruccione, A. Sigal, D. Hardie, G. Marais, M. Hsiao, S. Korsman, M. A. Davies, L. Tyers, I. Mudau, D. York, C. Maslo, D. Goedhals, S. Abrahams, O. Laguda-Akingba, A. Alisoltani-Dehkordi, A. Godzik, C. K. Wibmer, B. T. Sewell, J. Lourenço, L. C. J. Alcantara, S. L. K. Pond, S. Weaver, D. Martin, R. J. Lessells, J. N. Bhiman, C. Williamson, and T. de Oliveira (2020) Emergence and rapid spread of a new severe acute respiratory syndrome-related coronavirus 2 (SARS-CoV-2) lineage with multiple spike mutations in South Africa. medRxiv. 2020.12.21.20248640.

56. Pearson, C. A. B., T. W. Russell, N. Davies, A. J. Kucharski, 
CMMID COVID-19 working group, W. J. Edmunds, and R. M. Eggo (2021) Estimates of severity and transmissibility of novel South Africa SARS-CoV-2 variant 501Y. V2. https://cmmid. github.io/topics/covid19/sa-novel-variant.html.

57. Hoffmann, M., P. Arora, R. Groß, A. Seidel, B. F. Hörnich, A. S. Hahn, N. Krüger, L. Graichen, H. Hofmann-Winkler, A. Kempf, M. S. Winkler, S. Schulz, H. M. Jäck, B. Jahrsdörfer, H. Schrezenmeier, M. Müller, A. Kleger, J. Münch, and S. Pöhlmann (2021) SARS-CoV-2 variants B.1.351 and P.1 escape from neutralizing antibodies. Cell. 184: 2384-2393.

58. Public Health Emergency, Pause in the distribution of bamlanivimab/etesevimab. https:/www.phe.gov/emergency/events/ COVID19/investigation-MCM/Bamlanivimab-etesevimab/ Pages/bamlanivimab-etesevimab-distribution-pause.aspx.

59. Umair, M., A. Ikram, M. Salman, N. Badar, S. A. Haider, Z. Rehman, M. Ammar, M. S. Rana, and Q. Ali (2021) Detection and whole-genome sequencing of SARS-CoV-2 B.1.617.2 and B.1.351 variants of concern from Pakistan during the COVID-19 third wave. medRxiv. 2021.07.14.21259909.

60. Brown, K. A., E. Joh, S. A. Buchan, N. Daneman, S. Mishra, S. Patel, and T. Day (2021) Inflection in prevalence of SARS-CoV2 infections missing the N501Y mutation as a marker of rapid delta (B.1.617.2) lineage expansion in Ontario, Canada. medRxiv. 2021.06.22.21259349.

61. Khan, A., D. Q. Wei, K. Kousar, J. Abubaker, S. Ahmad, J. Ali, F. Al-Mulla, S. S. Ali, N. Nizam-Uddin, A. M. Sayaf, and A. Mohammad (2021) Preliminary structural data revealed that the SARS-CoV-2 B.1.617 variant's RBD binds to ACE2 receptor stronger than the wild type to enhance the infectivity. ChemBioChem. 22: 2641-2649.

62. Allen, H., A. Vusirikala, J. Flannagan, K. A. Twohig, A. Zaidi, COG-UK Consortium, N. Groves, J. Lopez-Bernal, R. Harris, A. Charlett, G. Dabrera, and M. Kall (2021) Increased household transmission of COVID-19 cases associated with SARS-CoV-2 variant of concern B.1.617.2: A national case-control study. https://khub.net/documents/135939561/405676950/Increased+ Household+Transmission+of+COVID-19+Cases+-+national+ case+study.pdf/7f7764fb-ecb0-da31-77b3-b1a8ef7be9aa.

63. Mlcochova, P., S. A. Kemp, M. S. Dhar, G. Papa, B. Meng, I. A. T. M. Ferreira, R. Datir, D. A. Collier, A. Albecka, S. Singh, R. Pandey, J. Brown, J. Zhou, N. Goonawardane, S. Mishra, C. Whittaker, T. Mellan, R. Marwal, M. Datta, S. Sengupta, K. Ponnusamy, V. S. Radhakrishnan, A. Abdullahi, O. Charles, P. Chattopadhyay, P. Devi, D. Caputo, T. Peacock, C. Wattal, N. Goel, A. Satwik, R. Vaishya, M. Agarwal, The Indian SARSCoV-2 Genomics Consortium (INSACOG), The Genotype to Phenotype Japan (G2P-Japan) Consortium, The CITIID-NIHR BioResource COVID-19 Collaboration, A. Mavousian, J. H. Lee, J. Bassi, C. Silacci-Fegni, C. Saliba, D. Pinto, T. Irie, I. Yoshida, W. L. Hamilton, K. Sato, S. Bhatt, S. Flaxman, L. C. James, D. Corti, L. Piccoli, W. S. Barclay, P. Rakshit, A. Agrawal, and R. K. Gupta (2021) SARS-CoV-2 B.1.617.2 Delta variant replication and immune evasion. Nature. 599: 114-119.

64. Planas, D., D. Veyer, A. Baidaliuk, I. Staropoli, F. GuivelBenhassine, M. M. Rajah, C. Planchais, F. Porrot, N. Robillard, J. Puech, M. Prot, F. Gallais, P. Gantner, A. Velay, J. Le Guen, N. Kassis-Chikhani, D. Edriss, L. Belec, A. Seve, L. Courtellemont, H. Péré, L. Hocqueloux, S. Fafi-Kremer, T. Prazuck, H. Mouquet, T. Bruel, E. Simon-Lorière, F. A. Rey, and O. Schwartz (2021) Reduced sensitivity of SARS-CoV-2 variant Delta to antibody neutralization. Nature. 596: 276-280.

65. Sheikh, A., J. McMenamin, B. Taylor, and C. Robertson (2021) SARS-CoV-2 Delta VOC in Scotland: Demographics, risk of hospital admission, and vaccine effectiveness. Lancet. 397: 24612462.

66. Lopez Bernal, J., N. Andrews, C. Gower, E. Gallagher, R.
Simmons, S. Thelwall, J. Stowe, E. Tessier, N. Groves, G. Dabrera, R. Myers, C. N. J. Campbell, G. Amirthalingam, M. Edmunds, M. Zambon, K. E. Brown, S. Hopkins, M. Chand, and M. Ramsay (2021) Effectiveness of Covid-19 vaccines against the B.1.617.2 (Delta) variant. N. Engl. J. Med. 385: 585-594.

67. Ong, S. W. X., C. J. Chiew, L. W. Ang, T. M. Mak, L. Cui, M. P. H. S. Toh, Y. D. Lim, P. H. Lee, T. H. Lee, P. Y. Chia, S. MaurerStroh, R. T. P. Lin, Y. S. Leo, V. J. Lee, D. C. Lye, and B. E. Young (2021) Clinical and virological features of SARS-CoV-2 variants of concern: A retrospective cohort study comparing B.1.1.7 (Alpha), B.1.315 (Beta), and B.1.617.2 (Delta). http:// dx.doi.org/10.2139/ssrn.3861566.

68. Faria, N. R., T. A. Mellan, C. Whittaker, I. M. Claro, D. D. S. Candido, S. Mishra, M. A. E. Crispim, F. C. S. Sales, I. Hawryluk, J. T. McCrone, R. J. G. Hulswit, L. A. M. Franco, M. S. Ramundo, J. G. de Jesus, P. S. Andrade, T. M. Coletti, G. M. Ferreira, C. A. M. Silva, E. R. Manuli, R. H. M. Pereira, P. S. Peixoto, M. U. G. Kraemer, N. Gaburo Jr, C. D. C. Camilo, H. Hoeltgebaum, W. M. Souza, E. C. Rocha, L. M. de Souza, M. C. de Pinho, L. J. T. Araujo, F. S. V. Malta, A. B. de Lima, J. D. P. Silva, D. A. G. Zauli, A. C. D. S. Ferreira, R. P. Schnekenberg, D. J. Laydon, P. G. T. Walker, H. M. Schlüter, A. L. P. Dos Santos, M. S. Vidal, V. S. Del Caro, R. M. F. Filho, H. M. Dos Santos, R. S. Aguiar, J. L. Proença-Modena, B. Nelson, J. A. Hay, M. Monod, X. Miscouridou, H. Coupland, R. Sonabend, M. Vollmer, A. Gandy, C. A. Prete Jr, V. H. Nascimento, M. A. Suchard, T. A. Bowden, S. L. K. Pond, C. H. Wu, O. Ratmann, N. M. Ferguson, C. Dye, N. J. Loman, P. Lemey, A. Rambaut, N. A. Fraiji, M. D. P. S. S. Carvalho, O. G. Pybus, S. Flaxman, S. Bhatt, and E. C. Sabino (2021) Genomics and epidemiology of the P.1 SARSCoV-2 lineage in Manaus, Brazil. Science. 372: 815-821.

69. Outbreak.info, P.1 Lineage Report. https://outbreak.info/situationreports?pango $=$ P.1.

70. Naveca, F. G., V. Nascimento, V. C. de Souza, A. de Lima Corado, F. Nascimento, G. Silva, Á. Costa, D. Duarte, K. Pessoa, M. Mejía, M. J. Brandão, M. Jesus, L. Gonçalves, C. F. da Costa, V. Sampaio, D. Barros, M. Silva, T. Mattos, G. Pontes, L. Abdalla, J. H. Santos, I. Arantes, F. Z. Dezordi, M. M. Siqueira, G. L. Wallau, P. C. Resende, E. Delatorre, T. Gräf, and G. Bello (2021) COVID-19 in Amazonas, Brazil, was driven by the persistence of endemic lineages and P.1 emergence. Nat. Med. 27: 1230-1238.

71. Coutinho, R. M., F. M. D. Marquitti, L. S. Ferreira, M. E. Borges, R. L. P. da Silva, O. Canton, T. P. Portella, S. Poloni, C. Franco, M. M. Plucinski, F. C. Lessa, A. A. M. da Silva, R. A. Kraenkel, M. A. de Sousa Mascena Veras, and P. I. Prado (2021) Modelbased estimation of transmissibility and reinfection of SARSCoV-2 P.1 variant. medRxiv. 2021.03.03.21252706.

72. Dejnirattisai, W., D. Zhou, P. Supasa, C. Liu, A. J. Mentzer, H. M. Ginn, Y. Zhao, H. M. E. Duyvesteyn, A. Tuekprakhon, R. Nutalai, B. Wang, C. López-Camacho, J. Slon-Campos, T. S. Walter, D. Skelly, S. A. C. Clemens, F. G. Naveca, V. Nascimento, F. Nascimento, C. F. da Costa, P. C. Resende, A. Pauvolid-Correa, M. M. Siqueira, C. Dold, R. Levin, T. Dong, A. J. Pollard, J. C. Knight, D. Crook, T. Lambe, E. Clutterbuck, S. Bibi, A. Flaxman, M. Bittaye, S. Belij-Rammerstorfer, S. C. Gilbert, M. W. Carroll, P. Klenerman, E. Barnes, S. J. Dunachie, N. G. Paterson, M. A. Williams, D. R. Hall, R. J. G. Hulswit, T. A. Bowden, E. E. Fry, J. Mongkolsapaya, J. Ren, D. I. Stuart, and G. R. Screaton (2021) Antibody evasion by the P.1 strain of SARSCoV-2. Cell. 184: 2939-2954.

73. Falcone, M., G. Tiseo, B. Valoriani, C. Barbieri, S. Occhineri, P. Mazzetti, M. L. Vatteroni, L. R. Suardi, N. Riccardi, M. Pistello, D. Tacconi, and F. Menichetti (2021) Efficacy of bamlanivimab/ etesevimab and casirivimab/imdevimab in preventing progression to severe COVID-19 and role of variants of concern. Infect. Dis. 
Ther: 10: 2479-2488.

74. Wang, P., R. G. Casner, M. S. Nair, M. Wang, J. Yu, G. Cerutti, L. Liu, P. D. Kwong, Y. Huang, L. Shapiro, and D. D. Ho (2021) Increased resistance of SARS-CoV-2 variant P.1 to antibody neutralization. Cell Host Microbe. 29: 747-751.

75. Messali, S., A. Bertelli, G. Campisi, A. Zani, M. Ciccozzi, A. Caruso, and F. Caccuri (2021) A cluster of the new SARS-CoV-2 B.1.621 lineage in Italy and sensitivity of the viral isolate to the BNT162b2 vaccine. J. Med. Virol. 93: 6468-6470.

76. Acevedo, M. L., L. Alonso-Palomares, A. Bustamante, A. Gaggero, F. Paredes, C. P. Cortés, F. Valiente-Echeverría, and R. Soto-Rifo (2021) Infectivity and immune escape of the new SARS-CoV-2 variant of interest Lambda. medRxiv. 2021.06.28. 21259673

77. Amin, M., M. K. Sorour, and A. Kasry (2020) Comparing the binding interactions in the receptor binding domains of SARSCoV-2 and SARS-CoV. J. Phys. Chem. Lett. 11: 4897-4900.

78. Cele, S., I. Gazy, L. Jackson, S. H Hwa, H. Tegally, G. Lustig, J. Giandhari, S. Pillay, E. Wilkinson, Y. Naidoo, F. Karim, Y. Ganga, K. Khan, M. Bernstein, A. B. Balazs, B. I. Gosnell, W. Hanekom, M. Y. S. Moosa, Network for Genomic Surveillance in South Africa, COMMIT-KZN Team, R. J. Lessells, T. de Oliveira, and A. Sigal (2021) Escape of SARS-CoV-2 501Y.V2 from neutralization by convalescent plasma. Nature. 593: 142146.

79. Zahradník, J., S. Marciano, M. Shemesh, E. Zoler, D. Harari, J. Chiaravalli, B. Meyer, Y. Rudich, C. Li, I. Marton, O. Dym, N. Elad, M. G. Lewis, H. Andersen, M. Gagne, R. A. Seder, D. C. Douek, and G. Schreiber (2021) SARS-CoV-2 variant prediction and antiviral drug design are enabled by RBD in vitro evolution.
Nat. Microbiol. 6: 1188-1198.

80. Eguia, R., K. H. D. Crawford, T. Stevens-Ayers, L. KelnhoferMillevolte, A. L. Greninger, J. A. Englund, M. J. Boeckh, and J. D. Bloom (2021) A human coronavirus evolves antigenically to escape antibody immunity. PLoS Pathog. 17: e1009453.

81. Kistler, K. E. and T. Bedford (2021) Evidence for adaptive evolution in the receptor-binding domain of seasonal coronaviruses OC43 and 229e. eLife 10: e64509.

82. Zhou, T., Y. Tsybovsky, A. S. Olia, J. Gorman, M. A. Rapp, G. Cerutti, P. S. Katsamba, A. Nazzari, A. Schön, P. Wang, J. Bimela, W. Shi, I. T. Teng, B. Zhang, J. C. Boyington, G. Y. Chuang, J. M. Sampson, M. Sastry, T. Stephens, J. Stuckey, S. Wang, R. A. Friesner, D. D. Ho, J. R. Mascola, L. Shapiro, and P. D. Kwong (2020) A pH-dependent switch mediates conformational masking of SARS-CoV-2 spike. bioRxiv. 2020.07.04.187989.

83. Benton, D. J., A. G. Wrobel, P. Xu, C. Roustan, S. R. Martin, P. B. Rosenthal, J. J. Skehel, and S. J. Gamblin (2020) Receptor binding and priming of the spike protein of SARS-CoV-2 for membrane fusion. Nature. 588: 327-330.

84. Miersch, S., Z. Li, R. Saberianfar, M. Ustav, J. B. Case, L. Blazer, C. Chen, W. Ye, A. Pavlenco, M. Gorelik, J. G. Perez, S. Subramania, S. Singh, L. Ploder, S. Ganaie, R. E. Chen, D. W. Leung, P. P. Pandolfi, G. Novelli, G. Matusali, F. Colavita, M. R. Capobianchi, S. Jain, J. B. Gupta, G. K. Amarasinghe, M. S. Diamond, J. Rini, and S. S. Sidhu (2021) Tetravalent SARSCoV-2 neutralizing antibodies show enhanced potency and resistance to escape mutations. J. Mol. Biol. 433: 167177.

85. Janson, G., C. Zhang, M. G. Prado, and A. Paiardini (2017) PyMod 2.0: improvements in protein sequence-structure analysis and homology modeling within PyMOL. Bioinform. 33: 444-446.

Publisher's Note Springer Nature remains neutral with regard to jurisdictional claims in published maps and institutional affiliations. 